\title{
Functional and Basis Path Method for Testing on the Development of WEB Show Window of Crysanthemun Flowers
}

\author{
Olga Melo, Anthon Arie Kimbal, Robby Tangkudung \\ Dept. Informatics Engineering \\ State Polytechnic of Manado Indonesia
}

\begin{abstract}
Chrysanthemum flowers are flowers that grow in areas with an altitude of 600-900 meters above sea level. Tomohon City which is located at an altitude has characteristic suitable for cultivation of chrysanthemum flowers. The city government of Tomohon built a show window of chrysanthemum flowers showcase and is expected to be a tourist icon of Tomohon city flower. To further introduce chrysanthemum flowers and activities related to chrysanthemum flowers such as the flower festival of Tomohon city it is necessary to conduct WEB development containing chrysanthemum flower information and test on the web development result. The complexity of web development requires a comprehensive development method. Tools in the form of analysis diagrams and designs such as data flow diagrams, entity relationship diagrams used in this study for analysis activities system requirements, design and implementation of WEB can run well. Strategy to get a web that is good then the black-box test and also white-box. Black-box is used to test the functional of the program with no error and white-box results using the base path testing method using graph theory that produces the optimal test that is all independent paths that may be executed at least once, the logical decision that there is right from the logic of web procedural.
\end{abstract}

\section{Keywords}

Web, test, black-box, white-box

\section{INTRODUCTION}

Chrysanthemum flowers are ornamental flowers that have high economic value and high commercial value as well. Chrysanthemum flowers are very well grown in the plains of medium and highlands. Chrysanthemum flowers are a compound interest consisting of a set of florets (disk florets), centered in the shape of a tube and in a ray floret in the shape of a ribbon around it [15]. Chrysanthemum consumers usually like healthy chrysanthemum flowers that can be seen from the appearance of a perfect bloom, the stalk is upright and sturdy so it will make this flower can last long when it is cut [6].

Chrysanthemum plants are also very well grown in Tomohon city in North Sulawesi province [14]. The location of cultivation and chrysanthemum production in Tomohon is at Kakaskasen II Village with altitude of place is $600-700 \mathrm{~m}$ above sea level, and has a mild climate suitable for chrysanthemum growth with air temperature between $190 \mathrm{C}-290 \mathrm{C}$ [10].

The condition of the fertile soil and the cool air make Tomohon very suitable for cultivating various kinds of flowers and vegetables [14]. At the foot of Mount Lokon the colorful chrysanthemums grow in the plantation fields of the people. With a planting area of about 90 hectares and a harvest area of about 70 hectares, flower production reaches about seven million buds or stems [2].

The flowers produced by Tomohon city flower growers became more popular in the archipelago and internationally after the Tomohon International Flower Festival (TIFF in 2006) [3]. Trials continue to be conducted by the Tomohon municipal government with the aim of obtaining chrysanthemum flowers that meet the export standard in the Kakaskasen Village II show window, Tomohon Utara District. Show Window is built for flower farmers so they can do all activities related to flowers [3].

Tomohon city government built this estalase in order to become a nursery area, learning, cultivation, distribution of flower production, and can be used as one of the icon of Tomohon city tourist destination. It is hoped that this could have an effect multiplier effect on the people of Tomohon. At present the profits to be gained from chrysanthemum sales are $53.33 \%$ [14]

Show Window Tomohon city in 2013 has been built 7 green house that operates as a test site for planting chrysanthemum flowers, and in 2015 will be built 3 green house so that there are total 10 green house [2]. The production of every green house reaches 5 thousand buds once harvest in the period of 3 to 4 months. In addition to adding green houses to support the export program, the government is also continuing to coach 30 groups of flower farmers in Tomohon, in order to develop production [3].

The effort to increase the selling power of the development of this chrysanthemum flower and promote the city of tomohon as the city of interest with various activities and resources available then it is necessary to provide the means of management information system [13]. One effective tool is digital based information that is web with various content in it. Web content can affect buyer behavior, opinions and important decisions of WEB users [1]. Therefore in the right sense to build faster web information.

Now a days the internet is used by adults to search for information on the WEB, as many as $92 \%$ of Americans use the internet to find the information they need [11]. Indonesia internet usage is very high, this is shown by the results of research from an international agency (international word statsa) who conducted a survey of technological developments in Indonesia in 2012. This development shows that $61 \%$ of internet users are from mobile phones. Feomena shows that the WEB and the coten in it more easily accessible without the need to use a computer device that is difficult to carry.

Research on WEB content has been done since the 1990s. It is also done by google to find out the truths of web content [22].

Based on some of the above conditions then this research should be done in order to available a container that can accommodate the data of chrysanthemum flowers, activities related to the interest in digital form so that data can be spread quickly using the internet network for those who need or for anyone. The focus of this research on two areas: first is how to implement chrysanthemum information and activities related to chrysanthemum result from the show window into web content 
and second is to test the quality of the web before it will be uploaded to the server The web. So later the web with chrysanthemum flower content can be a web that can be an alternative for society and the city government Tomohon to promote chrysanthemum Tomohon City results and activities that exist globally so expected to support economic and community development and city Tomohon.

This research aims to (1) perform system requirement analysis needed in design and development of model show window of chrysanthemum flower farming in Tomohon city, (2) make design of information system of cultivation technology technology of chrysanthemum kulo flowers and riri according to result of system requirement analysis, (3) create prototype computer program, (4) do the testing of web content.

\section{RESEARCH METODOLOGI}

\subsection{Location and Time}

This research was conducted in Tomohon city area that is Kakaskasen II village with time for 1 year that is 2017 .

\subsection{Stage of Research}

Research stages are needed to assist in the preparation and implementation of the research, which is planned.

Figure. 1, is a block diagram above describes the stages of research to be conducted during the study. The research begins with a survey with the aim to get the data for web system analysis that will be built. The design of the system will focus on the flow of data, the appearance of the system in a structured.

Development and implementation of the system using PHP programming language with MSql database. Implementation testing to see the capability or quality of content from the web using respondents [16].

\subsection{Research Methode}

The method used to obtain data, describe the system and test in this study is adapted from the Waterfall method [9].

- Interview method, this method is used to Identify problems and get the needs of the system

- Field study method using observation study and collecting scientific data using literature study. This method is used today for problem identification and getting needs from the system.

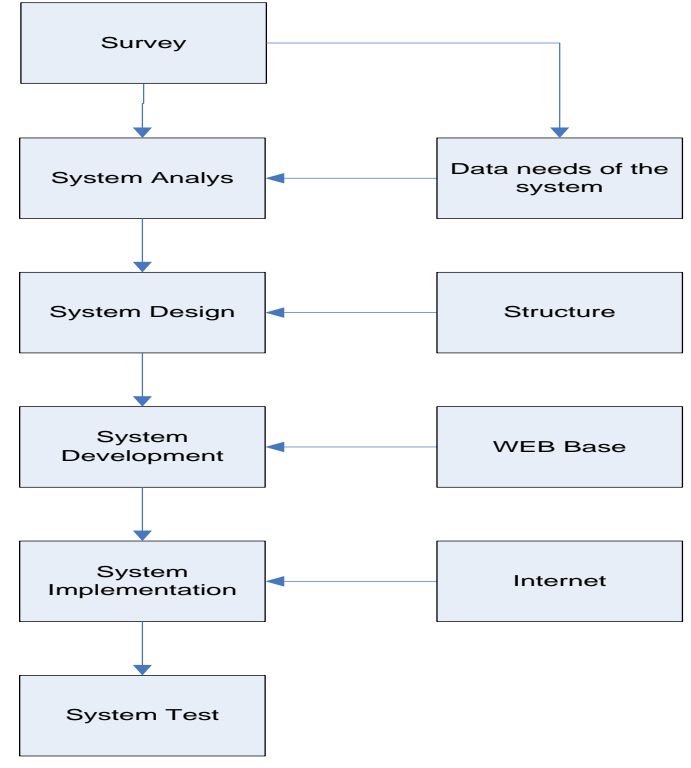

Fig 1: Stage of research

- Questionnaire method, this method is used for problem identification. And get the needs of the system and testing the web system.

- Method of architecture is a method that will be used to describe the use of system technology in an integrated system.

- Evaluation through WEB Testing interface program using respondents with questionnaire method to test web performance[24].

\subsection{Study Design}

The research design for web system development is:

- Literature Studies, literature study is conducted to collect the reference that will be the sources of material that includes: hand book, journals, papers / articles and previous studies related to the system to be designed and applied

- Analysis, design and implementation of the application.

- System performance analysis.

- Preparation of reports

\subsection{Research Instrument}

This research uses several instruments to support system analysis and development :

- A computer or laptop (minimum Intel 3 processor).

- Software support: PHP, javaskript and mysql [18].

- Tools: modem and printer.

- Internet.

- Network.

- Server.

\subsection{Analisys System Design}

The tools needed to analyze and design the system in this study are as follows[8] :

- Flow chart, used to analyze the workings of systems and 
programs

- Data Flow diagram, will be used to analyze the data flow and design that occurs on the system to be built

- Entity Relationship Diagram, will be used to design the database by analyzing the relationship between entities in the system

- Use case diagram, used to analyze who has the right to use system functions [20].

Figure. 2, The design of the proposed system architecture in this study illustrates that the integrated technology in this study is a web server as a data center, internet network to connect between the server and client and the device that allows to become a client. The design of the proposed system is based on a unity of conceptual framework as in figure. 3 .

Figure. 3, This research aims to design a web from model show window for cultivation of chrysanthemum kulo and riri based on information technology.

\subsection{Study Design}

The research design for web system development is:

- Literature Studies, Liliterature study is conducted to collect the reference that will be the sources of material that includes: hand book, journals, papers / articles and previous studies related to the system to be designed and applied

- Analysis, Design and implementation of the application.

- System performance analysis.

- Preparation of reports

\subsection{Research Instrument}

This research uses several instruments to support system analysis and development :

- A computer or laptop (minimum Intel 3 processor).

- Software support: PHP, javaskript and mysq1 [18].

- Tools: modem and printer.

- Internet.

- Network.

- Server.

\subsection{Analisys System Design}

The tools needed to analyze and design the system in this study are as follows[8] :

- Flow chart, used to analyze the workings of systems and programs

- Data Flow diagram, will be used to analyze the data flow and design that occurs on the system to be built

- Entity Relationship Diagram, will be used to design the database by analyzing the relationship between entities in the system

- Use case diagram, used to analyze who has the right to use system functions [20].

Figure. 3, the design of the proposed system architecture in this study illustrates that the integrated technology in this study is a web server as a data center, internet network to connect between the server and client and the device that allows to become a client. The design of the proposed system is based on a unity of conceptual framework as in Figure. 3.

Figure. 3, This research aims to design a web from model show window for cultivation of chrysanthemum kulo and riri

based on information technology.

\section{RESULT AND DISCUSSION}

Based on the needs of the system in this study, for the development of WEB produce several things, such as:

\subsection{Functional system}

The analysis of system requirements then generated some functions that must exist on the web that will be developed, namely:

\subsubsection{Input functions:}

The function of the system that can be used to enter information, upload images and video.

\subsubsection{Process functions:}

Functions that perform the processes required to display nursery information, cultivation, production and show window circumstances. As well as a function to display activities related to chrysanthemum flowers and also with an international flower festival in Tomohon city.

\subsubsection{Output function:}

The function of the system that displays the information in the form of writing as well as images of chrysanthemum flowers.

\subsection{Interface}

Generally based on the results of the needs analysis then the web interface system design can be seen on the main menu web system figure.4,5,6

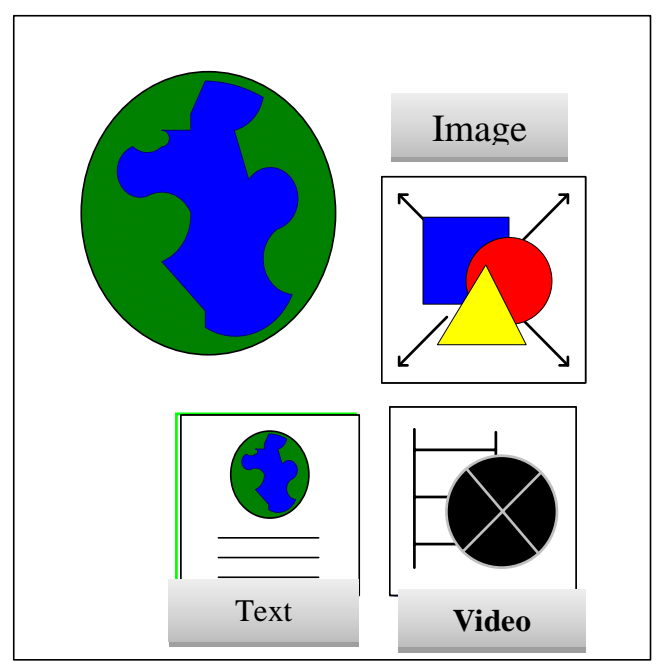

Fig 2: Conceptual 


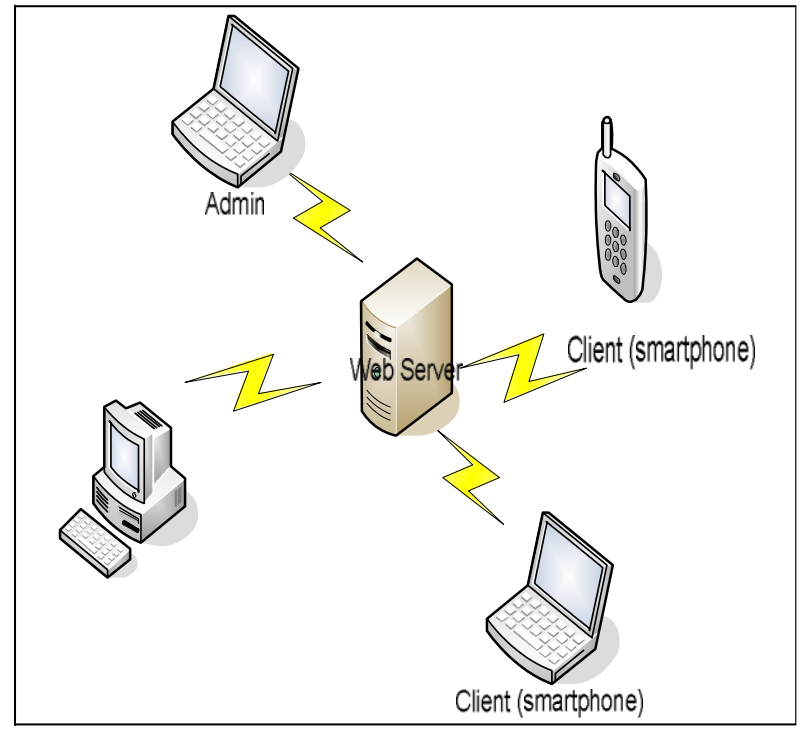

Fig 3: Arsitektur system

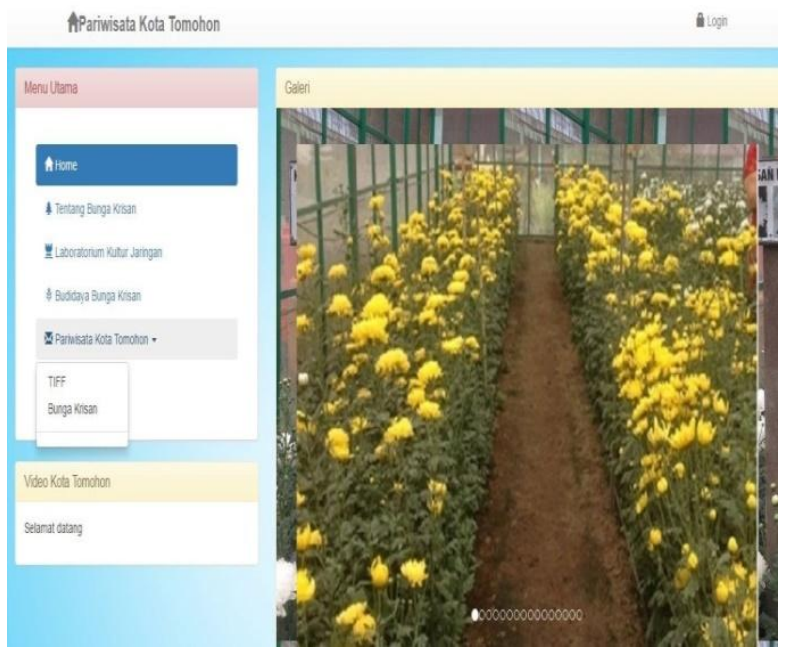

Fig 4: The main menu of the web

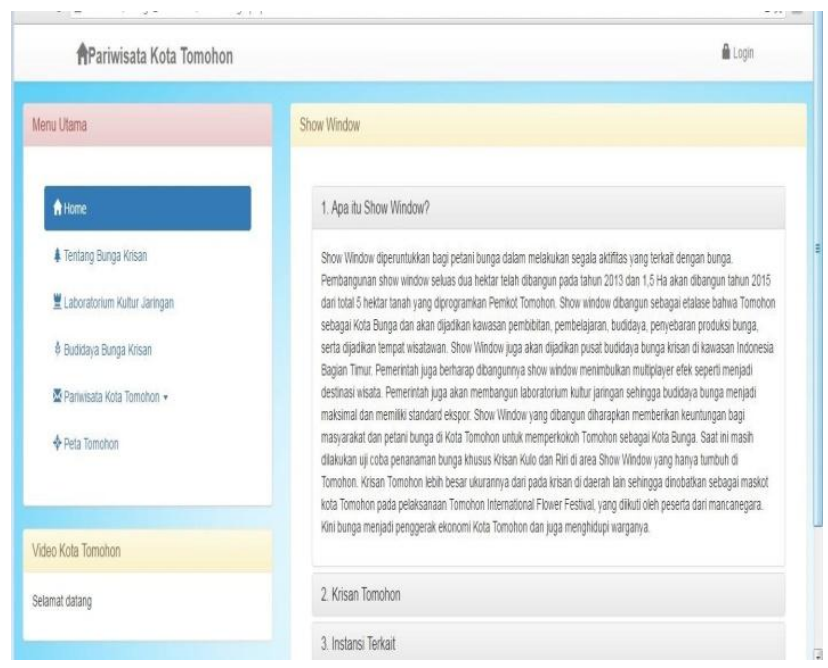

Fig 5: Show window

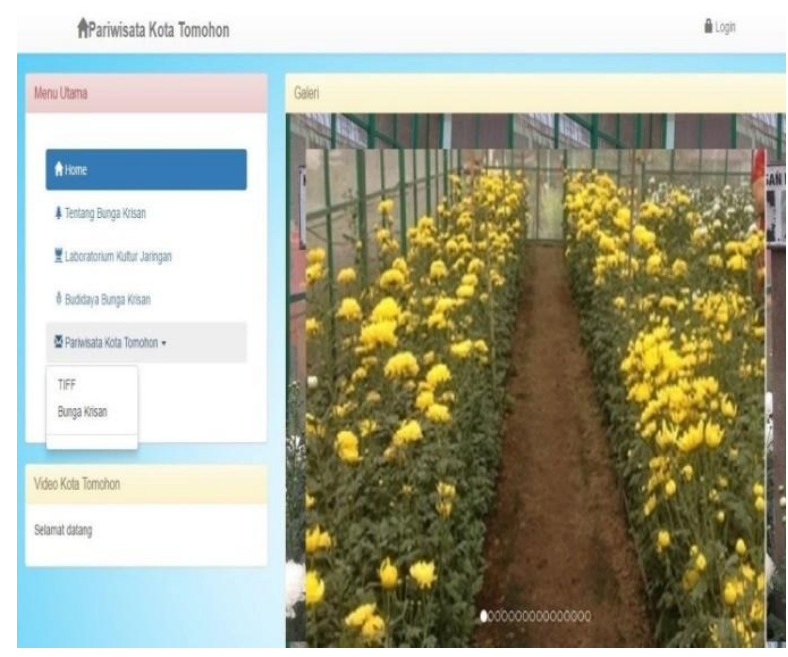

Fig 6: Flower galery

Figure. 6 is a display of the application interface consists of admin, master, ordering, purchasing, warehouse, production, accounting. Each menu integrates one with another menu.

\subsection{Testing}

Tests conducted on the system using blackbox testing methods and testing using respondents. The blackbox method, ie the test method against the application or program regardless of the data structure of the program [20]. The test that will be used in this research is the whitebox method proposed by Thomas McCabe[23]

Table 1. Fungsional test

\begin{tabular}{|c|c|c|c|}
\hline $\begin{array}{c}\text { Class } \\
\text { Test }\end{array}$ & $\begin{array}{c}\text { Technique } \\
\text { Testing }\end{array}$ & $\begin{array}{c}\text { Scenario } \\
\text { testing }\end{array}$ & Results of Test \\
\hline $\begin{array}{l}\text { Auth } \\
\text { entif } \\
\mathrm{i} \\
\text { kasi } \\
\text { Serv } \\
\text { er }\end{array}$ & Black Box & $\begin{array}{l}\text { Admin can } \\
\text { add data to the } \\
\text { server either, } \\
\text { image, video } \\
\text { or data } \\
\text { through typing } \\
\text { process by } \\
\text { first login }\end{array}$ & $\begin{array}{l}\text { Data uploaded to the } \\
\text { server can be } \\
\text { processed by the } \\
\text { system. The system } \\
\text { can perform the } \\
\text { admin login process, } \\
\text { then save the admin } \\
\text { sessions during the } \\
\text { login process, and } \\
\text { disable or delete } \\
\text { admin data on the } \\
\text { session when the } \\
\text { administrator has } \\
\text { logged out, } \\
\text { consequently the } \\
\text { system can no longer } \\
\text { be accessed } \\
\text { (Success) }\end{array}$ \\
\hline $\begin{array}{l}\text { Auth } \\
\text { etifik } \\
\text { asi } \\
\text { client }\end{array}$ & Black Box & $\begin{array}{l}\text { Users on the } \\
\text { client side can } \\
\text { access the } \\
\text { permitted } \\
\text { menu on the } \\
\text { web }\end{array}$ & $\begin{array}{l}\text { Users can access all } \\
\text { the existing menu } \\
\text { means the system } \\
\text { receives the process } \\
\text { from the user for the } \\
\text { desired information } \\
\text { (Success) }\end{array}$ \\
\hline
\end{tabular}

Table. 1 is the result of functional testing performed using blackbox testing techniques and is a summary of the trials that have been done. Overall the test was successful with no web functionality that could not meet the specified requirements. The use of blackbox method to test all parts of the system functions such as login and data processing with results as expected. 
Base path testing is a control structure testing technique and includes whitebox testing [19]. This study is aimed at measuring the logic complexity of the procedure design for the set base guidance of the execution path. Testing on a set basis is guaranteed to use every statement within the program at least once at test [23]. Testing is done with the help of Flowgraph Notation which is transformed from flowchart based on program procedure [19].

This test researchers do after testing blackbox and program procedures used for testing whitebox is TIFF menu that is used by web admin. Tiff menu is a menu on the WEB and can display information activities Tomohon International Flower Festival (TIFF) whose contents can be added, edit, delete by admin.

\section{Explanation of Tiff menu usage by admin}

\section{Show menu}

Do want to fill in the data, if yes type news and upload photos, whether want to be saved if yes show the data successfully saved. Otherwise the process is void. Looping

- If not save if any data will be deleted

- If yes, select data and photos then delete data and show successful data deleted

- If you want to edit the data, input data and photo changes, when it is saved and show the message successfully edited

- Do looping if not

- Show menu

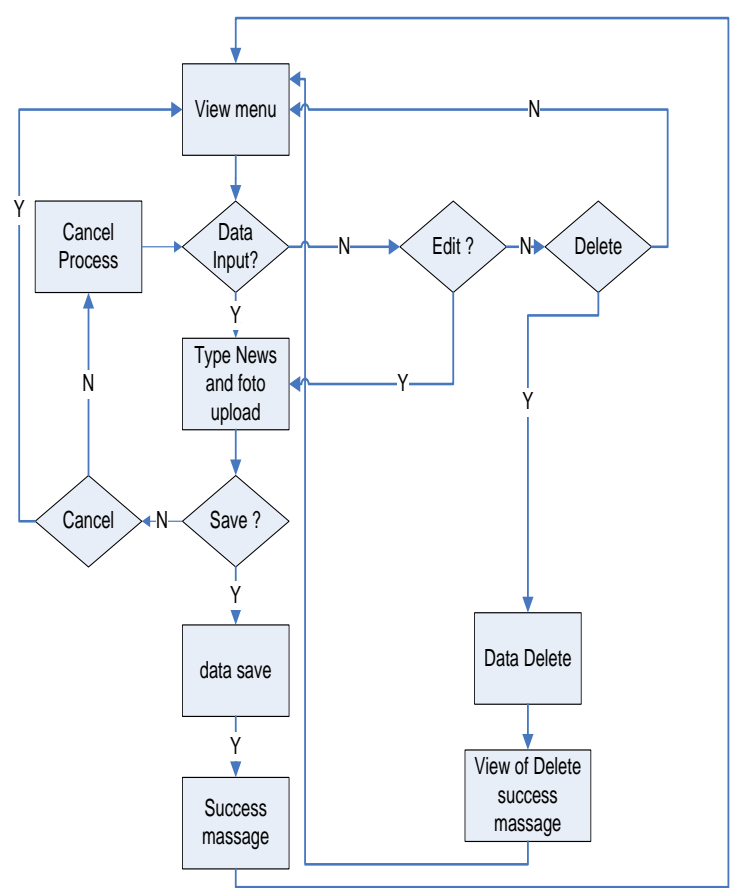

Fig 7: Flowchart menu TIFF

Figure 7 is a flowchart diagram for the tiff menu used for testing in this study. In fig. 7 illustrated that there are 5 logical decisions that will be tested whether it is correct.

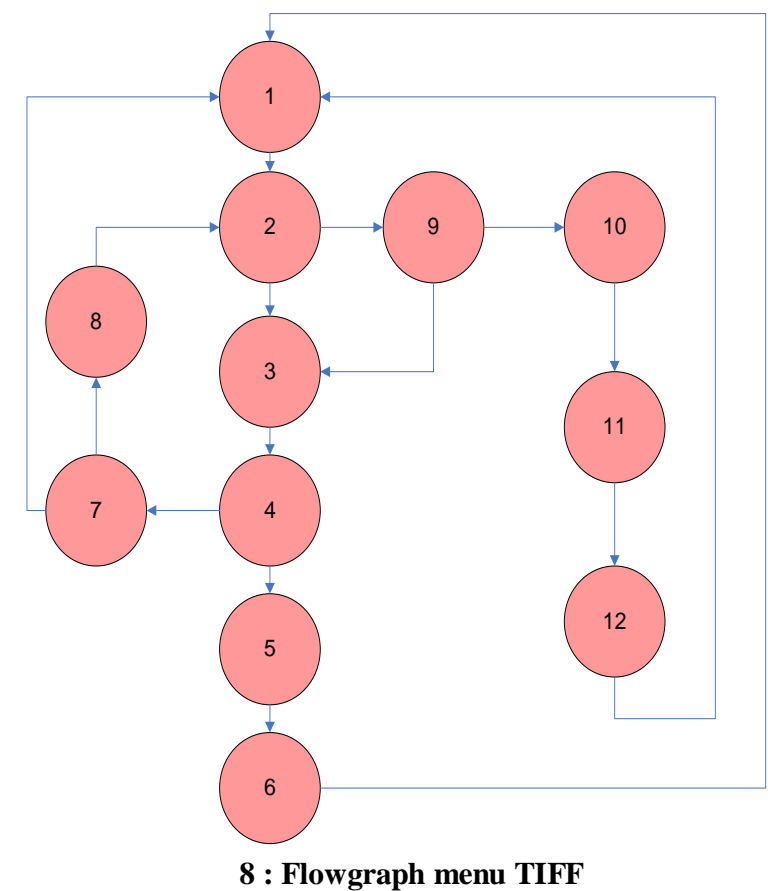

Fig

Figure. 8 is a flowgraph diagram which is a transformation of the flowchart in figure.7. Based on Figure. 8 is done whitebox testing using basis path.

After analyzing and transforming the flowchart into the flowgraph form, it will calculate the Cyclomatic Complexity of the flowgraph to quantitatively measure the logical complexity of the procedure on the TIFF menu by the admin so as to know the number of independent paths in the basis set and to give the upper limit for the number of tests to be performed [19]

Calculation of Cyclomatic Complexity using the formula

$$
V(G)=E-N+2
$$

The formula (1) is the formula used to determine the logical complexity of the procedure. The sum of $\mathrm{E}=$ edge is 16 , the sum of $\mathrm{N}=$ nodes is 12 .

The result of the calculation is $16-12+2=6$

This means that the maximum number of paths on the TIFF menu is 6 independent lines and matches the design for test execution that all statements have been executed as below,

Path $1: 1,2,3,4,7,1$

Path $2: 1,2,3,4,7,8,2,3,4,5,6,1$

Path $3: 1,2,3,4,7,8,2,9,3,4,5,6,1$

Path $4: 1,2,3,4,7,8,2,9,10,11,12,1$

Path $5: 1.2 .9,3,4,5,6,1$

Path $6: 1,2,3,10,11,12,1$

The above test shows the results of cyclomatic complexity and independent path is 6 so that testing is considered optimalThis test is optimal because it ensures that all independent paths that may exist in the program, logical decisions and all interfaces have been executed at least once [23]. Especially testing on the TIFF menu has been executed at least once for logical decisions and all interfaces. 


\section{CONCLUCION}

The conclusion of the results of this study is Based on the results of the analysis of the needs of web-based show window system then in can some content such as the main menu, flower gallery, flower laboratory, floriculture, tomohon city tourism and Tomohon city map. The design of web show window model based on system requirement analysis needed in design and development of model show window of chrysanthemum cultivation in Tomohon city, the prototype of computer program is divided into 2 that is admin section and user, the test done to web contents produce web Functionally functioning and the development of the test procedure produces a cyclomatis complexity of 6 equal to how many paths must be skipped during the program testing. This research is expected to be the basis for further research for a system that can accommodate and process a large number of social media-based data that can be used by various groups such as government, flower farmers, florists and consumers.

\section{ACKNOWLEDGMENTS}

Head of Manado State Polytechnic, Research Center and friends who have helped.

\section{REFERENCES}

[1] Adam Wierzbicki, Michal Kakol, Radoslaw Nielek $\quad 2017$ Understanding And Predicting Web Content Credibility Using The Content Credibility Corpus,Volume 53, Issue 5, Pages 1043-1061

[2] Badan Litbang Pertanian Pusat Penelitian dan Pengembangan Hortikultura; Procedures for Production of Core Seeds and Seeds of Chrysanthemum.Badan Litbang Pertanian Pusat Penelitian dan Pengembangan Hortikultura; 2003.

[3] Badan Litbang Pertanian, Balai Penelitian Agroklimat dan Hidrologi; Identification and Evaluation of Potential Land to Support Pri ma Tani in Kakaska sen Village Dua - Kec. Tomohon Utara, Tomohon City; Dinas Pertanian Tanaman Panga n, Perkebunan, Peternakan dan Perikanan Kota Tomohon, 2006, Laporan Tahunan; 2007

[4] D. Kahneman Thinking, 2011, fast and slow.Macmillan

[5] Ibrahim Al-Adwan, Munaf S. N, The Use of ZigBee Wireless Network for Monitoring and Controlling Greenhouse Climate, Al-D International Journal of Engineering and Advanced Technology (IJEAT) ISSN: 2249 - 8958, Volume-2, Issue-1, India. October 2012.

[6] I Kadek Wahyu Wiguna,I Made Anom SWijaya,I Made Nada.2015.

[7] Growth of Chrysanthemum (Crhysantemum) with various light color additions Ledselama Lights For 30 Days On Vegetative Phase, portal garuda

[8] Jumin, H.B. 2002, Agronomi. Fajar Interpratama Offset, Jakarta.

[9] Jogiyanto, Analisis dan Disain Sistem, Penerbit Andi, 2005.
[10] Kenneth E Kendall, System Analysis and Design 2nd Edition; Prentice Hall; New Jersey y, 2012.

[11] Kurniawan Budiarto, S. Yoyo., M. Ruud dan W. Sri, Budidaya Krisan; 2006.

[12] K. Purcell,2011,Search and email still top the list of most popular online activities,Pew Internet \& American Life Project

[13] Manish Mittal, Gaurav Tripathi, Deepa Chauhan and Atul Agarwal, Green House Monitor and Control Using Wireless System Network, VSRD-IJEECE, Vol. 2 (6), 2012, 337-345. Uttar Pradesh, INDIA.

[14] M. Raymond Jr, G. D. Scell, Management Information Si stem, New Jersey, Prentice Hall, 2004

[15] Natalis Rumengan.2016. Analysis of Chrysanthemum Flower Marketing in Kakaskasen II Sub-District Tomohon North Tomohon, e-jurnal unsrat

[16] Salinger, J. P. 1985.Commercial Flower Growing. Butterworths of New Zealand.p:163-177.

[17] Sabina Baraković, Lea Skorin-Kapov.,2017 Modelling the relationship between design/performance factors and perceptual features contributing to Quality of Experience for mobile Web browsing Computers in Human Behavior, Volume 74, September 2017, Pages 311-329

[18] Sinar Tani, 2009. BALITHI Towards Independence of Ornamental Plants Indonesia. Edisi 2 - 8 September 2009 No. 3319 Tahun XL.

[19] Sutarman. 2003. Building Web Applications with PHP and MySQL. Seri Pemrograman Web. Penerbit Graha Ilmu. Jakarta.

[20] R. Pressman, Sotfware Engineering, Andi, 2012.

[21] S. Rosa, Softwre Engineering, Bandung, Penerbit Modula, 2011

[22] Umi Nur Agustina. 2015. Effectiveness of Application of Management Information System of Electronic Puskesmas (Si mpustronik) In Puskesmas Gantrung Kecamatan Kebonsari Regency of Madiun, E- Journal (Diakses Pada Tanggal 20 Juni 2017)

[23] X.L. Dong, E. Gabrilovich, K. Murphy, V. Dang, W. Horn, C. Lugaresi, W. Zhan.2015 Knowledge-based trust: Estimating the trustworthiness of web sources, Proceedings of the VLDB endowment, 8 (9), pp. 938-949

[24] Z.Francisco, A Adity, P Ricardo, S Eric, Basis Path Analysis for Testing Complex System of Systems, Procedia Computer Science 20 ( 2013 ) 256-261.

[25] Kapoh, H., Doringin, F. and Taju, M.M., 2016. Design and Development of the Public Service Information: A Case Study of Villages in District East Tombariri, Minahasa-Indonesia. International Journal of Computer Applications, 156(12). 